\title{
Entrepreneurial Intention, Organizational Justice and Job Satisfaction as Determinants of Employees' Organizational Commitment: Evidence from Babcock University Nigeria
}

\author{
Lasun Gbadamosi \\ Department of Education, \\ Foundation \& Management, \\ Olabisi Onabanjo University, \\ Ago-Iwoye, Nigeria \\ lasungbadamosi@yahoo.com
}

\author{
Jonathan Chinaka Nwosu \\ Babcock University Ilishan, \\ Ilisan Remo, Ogun State, \\ Nigeria
}

\begin{abstract}
This study examined the effect of entrepreneurial intention, organizational justice, and job satisfaction on the organizational commitment of Babcock University Staff. Participants were 180 employees (male $=99$, female $=81)$ randomly selected from 4 faculties and the registry unit of the University. Measures of entrepreneurial intention, organizational justice, job satisfaction and organizational commitment were administered on the sample. Three (3) research hypotheses were formulated and tested using t-test, Multiple Regression Analysis and correlation analysis. Findings revealed that job satisfaction and organizational justice are the potent predictors of organizational commitment while entrepreneurial intentions will lead to turnover intentions among employees. Also, gender has no moderating effect on the relationship between the criterion and the independent variables. The implications of the findings are discussed.
\end{abstract}

Keywords: Job Satisfaction, Entrepreneurial Intention, Organizational Justice, Organizational Commitment

\section{Background of the Study}

From a global perspective, organizations in the 21 st century are characterized by continuous and rapid pace of change. This is due to economic and social developments that are increasingly driven by the advancement in technologies, global competition, organizational politics and job/personal characteristics. Every organization all the world over is established to achieve one goal or the other and activities within the organizations are initiated and determined by the workforce that makes up the institutions. Therefore, no organization can achieve its objectives without

Material published as part of this publication, either on-line or in print, is copyrighted by the Informing Science Institute. Permission to make digital or paper copy of part or all of these works for personal or classroom use is granted without fee provided that the copies are not made or distributed for profit or commercial advantage AND that copies 1) bear this notice in full and 2) give the full citation on the first page. It is permissible to abstract these works so long as credit is given. To copy in all other cases or to republish or to post on a server or to redistribute to lists requires specific permission and payment of a fee. Contact HPublisher@,InformingScience.orgH to request redistribution permission. adequate and effective inputs on its workforce. Ogunyemi (2007) established that "Workers constitute the oil that lubricates the factors of production that the entrepreneur expounds on the production process".

However, the need for factors that will enhance the commitment of employees to their career and organizations cannot be over-emphasized because it deter- 
mines employees' efficiency and efficacy. Also high productivity and performance of most organizations could not be realized without employees' support and contribution. All these have made organizational commitment in the recent time to emerge as a promising and contemporary area of research in Managerial Science and personnel development (Adebayo, 2006; Brown, 2003; Meyer \& Allen, 1991, 1997; Salami, 2008).

The importance of employees' commitment is quite evident if one considers prior research into the relationship between commitment and job satisfaction (Bateman \& Organ, 1983; Coetzee, 2004), workplace justice (Moorman, Niehoff, \& Organ, 1992), trust in and loyalty to the leader (Deluya, 1994) and perceptions of supervisors' fairness (Niehoff \& Moorman, 1993).

Job satisfaction is the degree of attachment an employee has for his or her job. Locke and Luthan (1998) opined that job satisfaction is the extent to which an individual employee is contentment with his / her job. Demir (2002) refers to job satisfaction as employees' feel of contentment and discontentment for a job. Brookfield (1998) found that individuals with high level of job satisfaction would have healthier physical and psychological records that very likely result in higher productivity and effectiveness in their job performance and staying longer with their organization. Okpara (2004) reported that when employees are sure that they can learn and gain from their current employers, their level of commitment to stay with that particular organization is higher. Also, Ayeni and Phopoola (2007) reported a strong relationship between job satisfaction and organizational commitment.

Justice causes integrity while organizational justice causes individual to be together in order to work effectively (Mehrdad, 2009). On the other hand, injustice destroys organizational integrity (Gholipour \& Ezzat, 2008). According to Greenberg (1990) "organizational Justice is related to staff perceptions of work fairness". In fact this phrase was used to explain and to analyze the role of fairness in the work place. Injustice or discrimination is the basis of all organizational harms, deflections and misdeeds. When injustice appears in different classes and importance of organization relationship, organization will regress. In a study conducted by Mehrdad (2009), it was shown that there is a meaningful relationship between organization justice dimension and organizational citizenship behaviour. Also, employees' perceptions of being treated fairly in the method by which rewards are allocated (procedural justice) they are more likely to feel satisfied with their job (Greenberg, 1990) and display greater affective commitment to the organization (Dreek, 2006).

Entrepreneurial Intentions is the feelings of having of one's organizations that is derived from personal and contextual factors (Bird, 1998 cited in Kickul \& Zaper, 2003). Past studies have found that strongest personal factors influencing entrepreneurial intentions are used for achievement, tolerance for ambiguity, locus of control, and risk-taking propensity (Brockhaus, 1982; Brockhaus \& Horwitz, 1986). Contextual, Bruno \& Tyebjee (1982) have found availability of resources, government influences, and accessibility of customers, suppliers and transportation to be predictive of entrepreneurial intentions. In addition, job displacement, limited advancement opportunities, frustration with current employers, management policies and practices, and changes in market have also been found to be strong motivational factor for why individual start their own business (Buther \& Moore, 1997; Dubini, 1989; Feinberg, 1984; Hisrish \& Bruss, 1985); Kickul \& Zaper, 2003).

Despite of numerous empirical studies among scholars (especially those from personnel management and productivity), previous empirical findings are still less encouraging and have been inconclusive. Be that as it may, further investigations are required to determine the impact of entrepreneurial intentions, organizational justice and job satisfaction on employees' organizational commitment. 
Most studies of the behavioural outcomes of entrepreneurial intention (Kickul \& Zaper, 2003), organizational justice (Marko et al., 2002), job satisfaction (Adams, 2005) and organizational commitment (Salami, 2008) have focused on employees in certain product manufacturing industries and not in academics. The present study therefore, expands the analysis to include academic environment especially the university setting. This would help in addressing the issue of imbalance and closing the existing gap. It is in view of this that this paper sets out to assess the entrepreneurial Intention, organizational justice and job satisfaction as determinants of organization commitment of Babcock University Employees.

\section{Research Hypotheses}

The following research hypotheses were formulated for testing at 0.05 alpha level.

Hol: There is no significant effect of entrepreneurial intentions, organizational justice and job satisfaction on employees' organizational commitment.

Ho2: There is no significant relative effect of entrepreneurial intentions, organizational justice and job satisfaction on employees' organizational commitment.

Ho3: Gender will not significantly pre-determine employees' organization commitment based on work ethics, organizational justice and job satisfaction.

\section{Methodology}

\section{Research Design}

This study adopted an ex-post facto survey research design where four standardized instruments (Questionnaires) were used to collect data from the respondents on the studied variables.

\section{Sample}

The sample comprised of 180 employees of Babcock University Ilisan Remo, Ogun State, Nigeria. Employees were drawn from four (4) faculties and the Registry Unit of the university. The selections of the participants were done through stratified random sampling technique. The mean age of the participants was 33.82 years with a standard deviation of 5.13 ranging from 27-55 years. The overall work experience of the participants was 8.21 years $(\mathrm{SD}=3.60)$.

\section{Measures}

(1) Organizational Justice Scale: The organizational justice were measured using Moorman's (199) organizational justice scale. The instrument is a two dimensional scale. Scales of procedural justice $(7$ items; range of scale $=1-5$; mean score of responses $=2.8$; $\mathrm{SD}=0.7 ; \quad \alpha=.90$ ) and relational justice ( 6 items; range of scale $=1-5$; mean score of responses $=3.5 ; \mathrm{SD}=0.9, \alpha=.81)$. Both scale have been associated with organizational commitment, job satisfaction, retaliation and mental health (Elovainio et al, 2001; Greenberg, 1990; Marko et al; and Scarlicki et al, 1997), and they were moderately interrelated $(\mathrm{r}=.30)$.

(2) Job Satisfaction Survey: A 36 item, nine (9) subscale measure, it is develop to assess employees attitude about certain aspect of their job by Spector (1997). The nine subscale include pay, promotion, supervision, fringe benefits, contingent rewards, operating condition, co-workers, nature of work and communication, it is a 6 - point likert scaling (strong agree to strongly disagree). The scale has internal consistency ranges from, 60 to. 91 (Okubanjo, 2009). 
(3) Entrepreneurial Intention: Two items from Crant (1996) were used to measure entrepreneurial intentions; 'I will probably own my own business one day' and 'It is likely that I will personal own a small business in the relatively near future" Also, tow additional items from Kickul \& Zapper (2001) were added; 'Being 'my own boss' is an important goal of mine', and 'I often hi of having my own business'. Responses to these items were indicated on a seven - point likert scale $(1=$ strongly disagree $-7=$ was .90 .

(4) Organizational Commitment Questionnaire: Organizational Commitment was measure using Meyer \& Allen's 91991) instrument. The instrument consist f 24 items and was designed to capture three dimensions of organization commitment, namely affective, continuance, and normative. Each subscale or dimension of commitment is measured by eight items. All sub - scales employ a five-point likert scale, ranging from strongly disagree (1) to strongly agree (5). The internal consistency (measured by Cronbach's alpha) for overall organisational commitment scale and for affective, continuance and normative sub-normative sub-scales in this study are $0.79,0.89,0.85$ and 0.85 respectively (Abdullah et.al, 2005).

\section{Procedure}

A set of questionnaires for assessing entrepreneurial intentions, organizational justice, job satisfaction, organizational commitment and demographic data information were administered on the sample with the help of two other colleagues. A total of 200 questionnaires were distributed out of which $180(90 \%)$ were useable for the data analysis.

\section{Data Analysis}

In order to facilitate the analysis of the statistics generated from the data, this study employs descriptive analysis, t-test, multiple Regression Analysis and correlation analysis. The dependent variable or criterion variable was organizational commitment while the determinant variables were entrepreneurial intention, organizational justice and job satisfaction.

Table 1: Model summary of the multiple regression analysis of the effect of entrepreneurial intentions, organizational justice, and job satisfaction on employees' organization commitment

\begin{tabular}{|c|l|l|l|l|l|l|l|l|l|}
\hline & $\mathrm{R}$ & $\mathrm{R}^{2}$ & $\begin{array}{l}\text { Adj. } \\
\mathrm{R}^{2}\end{array}$ & $\mathrm{SE}$ & \multicolumn{5}{|c|}{ Change Statistics } \\
\hline Model & & & & $\begin{array}{c}\mathrm{R}^{2} \\
\text { Change }\end{array}$ & $\begin{array}{c}\mathrm{F} \\
\text { Change }\end{array}$ & $\mathrm{d} \mathrm{f} 1$ & $\mathrm{~d}$ f 2 & $\begin{array}{l}\text { Sig. F } \\
\text { Change }\end{array}$ \\
\hline $\begin{array}{l}\text { Predictor } \\
\text { Variables }\end{array}$ & .886 & .851 & .851 & 2.139 & .851 & 207.186 & 3 & 178 & .000 \\
\hline
\end{tabular}

a. Predictions: (Constant), entrepreneurial intention, organisational justice, job satisfaction

b. Dependant Variable: Organisational Commitment

The results in Table 1 revealed that job satisfaction, organisational justice and entrepreneurial intentions combine to determine employees' organizational commitment $\quad\left(\mathrm{R}=886 ; \mathrm{R}^{2}=851\right.$; $\mathrm{F}(3,178)=207.186 ; \mathrm{P}<.05)$. This revealed that entrepreneurial intentions, organizational justice and job satisfaction accounted for $85.1 \%$ of the variance in the organizational commitment of workers. This finding rejected the hypothesis, which stated that there is no significant effect of entrepreneurial intentions, organisational justice and job satisfaction on employees' organiza- 
tional commitment. Thus, entrepreneurial intentions, organizational justice and job satisfaction are good predictors of employees' organizational commitment.

Table 2: Coefficients of relative contribution of entrepreneurial intentions, organizational justice and job satisfaction to the prediction of organisational commitment

\begin{tabular}{|l|l|l|l|l|l|}
\hline & \multicolumn{2}{|l|}{$\begin{array}{l}\text { Unstandardized } \\
\text { Coefficients }\end{array}$} & $\begin{array}{l}\text { Standardized } \\
\text { Coefficients }\end{array}$ & $\mathrm{t}$ & $\mathrm{Sig}$ \\
\hline & \multicolumn{1}{|c|}{$\mathrm{B}$} & \multicolumn{1}{|c|}{ SE } & Beta & & \\
\hline (Constant) & 19.419 & 1.388 & & 8.746 & .000 \\
Entrepreneurial Intentions & .109 & .016 & .041 & -.103 & .101 \\
Organizational Justice & .303 & .057 & .577 & 6.017 & .037 \\
Job Satisfaction & .308 & .022 & .630 & 8.298 & .000 \\
\hline
\end{tabular}

a. Dependent Variable: Organizational Commitment.

The results in Table 2 revealed the strength of causation of the predictor variables on the criterion variable. The most potent predictor of employees' organizational Commitment among the predictor variables of the study is job satisfaction $(\beta=630 ; \mathrm{t}=8.298 ; \mathrm{p}<.05)$. Organizational justice is the next potent factor $(\beta=577 ; \mathrm{t}=6.017 ; \mathrm{p}<.05)$. Entrepreneurial intentions $(\beta=.041, \mathrm{t}=-.103 ; \mathrm{p}$ $<.05)$ negates the prediction of employees' organizational commitment, which will results into turnover. The null hypothesis of no relative contribution of the predictor variables to the criterion variable was rejected by this finding.

Table 3: Results of t-test on the means of the variables of interest across categories of gender.

\begin{tabular}{|c|c|c|c|}
\hline Variable & Gend & & sig \\
\hline Affoctive Commitmont & $\begin{array}{l}\text { Male }(\mathrm{N}=99 \\
81)\end{array}$ & Female $(\mathrm{N}=$ & NS \\
\hline Continuance Commitment & 3.37 & 3.31 & NS \\
\hline Norminance Commitment & 2.96 & 3.01 & NS \\
\hline Job Satisfaction & 3.26 & 3.18 & NS \\
\hline Entrepreneurial Intentions & 3.88 & 3.85 & NS \\
\hline \multirow[t]{2}{*}{ Organizational Justice } & 1.45 & 1.07 & NS \\
\hline & 4.10 & 4.12 & \\
\hline
\end{tabular}

The results in Table 3 revealed the t-test on the means of the variables of interest. For all variables, the differences in the means are not significant. However, the null hypothesis that started that gender will not significantly pre-determine employees' organizational commitment based on entrepreneurial intentions, organizational justice and job satisfaction was sustained. The results indicate that in terms of gender, males and females demonstrate almost similar levels of reaction to entrepreneurial intentions, organizational justice, job satisfaction and organizational commitment, irrespective of its dimensions. 


\section{Discussion and Conclusion}

The finding of the study indicated that the independent variables: entrepreneurial intention, organizational justice and job satisfaction were significant predictors of employees' organizational commitment, the study further found that job satisfaction and organizational justice had higher individual predictive relationship with employees' organizational commitment, while entrepreneurial intentions negates organizational commitment. It is not surprising to find job satisfaction and organizational justice as the potent predictors because the results corroborate earlier studies (Ayeni \& Phopoola, 2007; Brook - filed, 1998, Okpara, 2004), which found job satisfaction to be a good predictor of organization and career commitment. This reason for this may be due to the reactions of individual employees to the job. These reactions according to Salami (2008) influence the development of the individual's commitment to the organization after forming comprehensive evaluations of the employing organization, its values, expectations and one's own future in it.

On the effect of gender on the various level of organizational commitment based on the predictor variables, results indicate that male and female employees demonstrate similar levels of reaction to entrepreneurial intentions, organizational justice and job satisfaction. Thus, gender did not significantly predetermine employees' organizational commitment based on the predictor variables.

More specifically, the results of this study revealed that when individual are not satisfied with their job and they have the feelings of psychological contract breach and perceived injustice being present in their workplace; there are tendencies of wanting to leave and not being committed. All these are related to organizational process and work attitudes which are related to organizational climate. Morris and Bloom (2002) rightly noted that " work attitude could mediate the effect of climate on employees' performance and organizational characteristics and on the hand could influence employees' commitment to their organization and their job satisfaction.

With the findings of this study it could be concluded that job satisfaction, and organizational justice would determine employees' organizational commitment while entrepreneurial intentions will lead to turnover intentions among employees. Job satisfaction and organizational justice however, are the most potent predictors of organizational commitment in academia.

\section{References}

Adebayo, D. O. (2006). The moderating effect of self-efficacy on job insecurity and organizational commitment among Nigeria public servants. Journal of Psychology in Africa, 16(1), 35-43.

Ayeni, C. O., \& Phopoola, S. O (2007). Work motivation, job satisfactions and organizational commitment of library personnel in academic and research libraries in Oyo State, Nigeria. Library Philosophy and Practice.

Bateman, T., \& Crant, M. (1993). The proactive component of organizational behaviour: A measure and correlates. Journal of Organizational Behaviour, 14, 103-118.

Brockhaus, R. H., \& Horwitz, P. S (1986). The psychology of the entrepreneur. In D. Sexton \& R. L. Smilor (Eds.), The art and science of entrepreneurship (pp. 39-57). England Cliffs, N.J; Prentice Hall.

Brown, B. B (2003). Employees' organizational commitment and their perception of supervisors' relations - oriented and task - oriented leadership behaviour. Dissertation submitted to the Faculty of Virginia Polytechnic Institute and State University in partial fulfillment of the requirements for the degree of Doctor of philosophy in Human Development. Falls church, Virginia.

Bruno, A. V., \& Tyebjee, T.,T. (1982). The environment of entrepreneurship. In C. Kent, D. Sexton, \& K. H. Vesper (Eds.), Encyclopaedia of entrepreneurship (288 -307). Englewood Cliffs, NJ; Prentice Hall.

Buttner, H., \& Moore, D (1997). Women's organizational exodus to entrepreneurship; Self-reported motivations and correlates with success. Journal of Small Business Management, 35(1), 34 -46. 
Coetzee, M. (2005). The fairness of affirmative actions: An organizational justice perspective. Dissertation summated to the faculty Economics and Management Sciences in partial fulfillment of the requirements of the degree of Doctor of philosophy in Human Resources Management at University of Pretoria.

Demir, C. (2002). Determining the level of job satisfaction of nurse working at Turkish military forces hospitals. Retrieved from http://www.findarticle.com

Dubini, P. (1989). The influence of motivations and environment on business start-ups: Some hints for public policies. Journal of Business Venturing, 4(1), 11- 26.

Feinberg, A. (1984). Inside the entrepreneur. Venture, 6(5), 80-85.

Gholipour, A., \& Ezzat, A. P. (2008). Injustice consequences in organization. Bardash E. Dovvom publication, Imam Sadegh University Research Centre Website.

Greenberg, J. (1990). Employee theft as a reaction to underpayment inequity: The hidden cost of pay cuts. Journal of Allied Psychology, 75, 561-568.

Kickul, J.. \& Zaper, J. A. (2001). Untying the knot: Do personal and organizational determinants influence entrepreneur intentions? Retrieved from http://www.findarticle.com

Mehrdad, G. C. (2009). The relationship between organizational justice and organizational citizenship behaviour. America Journal of Economics and Business Administration, 1(2), 171-174.

Meyer, J. P., \& Allen, N. J. (1991). A three component conceptualization of organizational commitment. Human Resources Management Review, 1(1), 61-89.

Niehoff, B. P. \& Moorman, R. H. (1993) Justice as a mediator of the relationship between methods of monitoring and organizational citizenship behaviour. Academy of Management Journal, 36(3), 527556.

Ogunyemi, A. O (2007). Perceived leadership style, motivation, and training as predictors of workers' productivity in a manufacturing industry in Lagos State. Ogun Journal of Counselling Studies, 1(1), 7683.

Okpara, J. O. (2004). Job satisfaction and organizational commitment: Are there differences between American and Nigerian Managers employed in the US MNCs in Nigeria? Academy of Business and Administrative Science, Briarcliffe College, Switzerland.

Salami, O. S. (2008). Demographic and psychological factors predicting organizational commitment among industrial workers. Anthropologist, 10(1) 31 - 38

\section{Biographies}

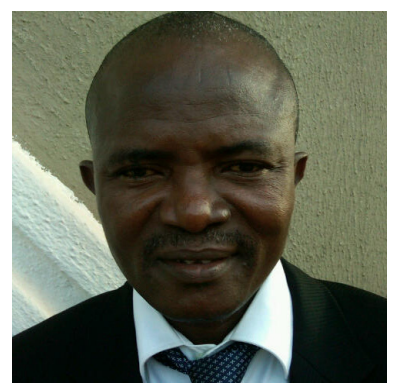

Lasun Gbadamosi PhD is a Professor of Human Resources, Planning and Management. He is currently the Dean of Faculty of Education, Olabisi Onabanjo University, Ago-iwoye, Ogun State, Nigeria.

Nwosu Jonathan Chinaka is a $\mathrm{PhD}$ candidate of Educational Management of Faculty of Education, Olabisi Onabanjo University, Ago-iwoye, Ogun State, Nigeria. Presently, he is the Deputy Registrar of Babcock University Ilishan, Ogun State, Nigeria. 